\title{
Reducing Spare Part Inventory Cost with Shortage Elimination through Probabilistic Economic Order Quantity
}

\author{
Andian Ari Istiningrum ${ }^{1}$, Laily Maudy Munandar ${ }^{2}$ and Sono ${ }^{3}$ \\ 1,2,3 Polytechnic of Energy and Mineral \\ andian.istiningrum@esdm.go.id
}

\begin{abstract}
The demand pattern of the fast-moving spare parts in Company $Z$ fluctuated every month and there were several months in which the demand was zero. In addition, Company $Z$ did not have a safety stock of these spare parts, so the risk of shortage of these spare parts was quite high. This study aimed to reduce fast-moving spare part inventory costs and prevent the risk of shortage by determining the optimal order quantity and re-ordering time. The inventory control model used to determine the optimal order quantity was the Probabilistic Economic Order Quantity (Probabilistic EOQ). This model is appropriate to use in conditions of unstable demand and it requires the calculation of safety stock to prevent shortage. Research data in the form of data on demand, lead time, purchasing cost, ordering cost, carrying cost, and shortage cost were collected from the company documents. The data that had been collected was then processed using an excel spreadsheet. Demand forecasting for the following 12 months was carried out using the Croston Method. Forecasting results were used as input to calculate the optimal order quantity on Probabilistic EOQ. Furthermore, data processing was run by calculating the safety stock and reorder point. The total inventory cost with Probabilistic EOQ was calculated and compared with the company's total inventory cost to determine whether Probabilistic EOQ is able to create inventory cost reduction. The results showed that Probabilistic EOQ enabled the company to reduce its inventory cost up to $57.85 \%$.

Keywords: inventory cost, shortage, economic order quantity
\end{abstract}

JEL $\quad:$ C22, C44, D24

DOI : 10.24002/kinerja.v25i2.4371

Received : 04/14/2021 Reviewed: 04/16/2021 Final Version: 04/24/2021 


\section{INTRODUCTION}

Energy holds a key role for companies in running their business because energy is the driving force of operations. Energy consumption is increasing in line with the rapid industrial growth. Energy-producing companies are demanded to be an energy provider that operates efficiently and effectively so that they can be used as an underpinning in ensuring fast and precise service for energy needs.

Energy-producing companies are responsible for ensuring the availability of energy by minimizing troubles and instabilities during the energy production process. The engine is one of the important aspects for energy-producing companies so that the reliability and availability of machines must be maintained well and the machine will be in ideal conditions (Budiningsih and Jauhari, 2017). Maintenance of machines needs to be carried out by energy-producing companies for predictive maintenance as well as corrective maintenance. The availability of spare parts plays an important role for energy-producing companies in carrying out machine maintenance and has a substantial impact on the inventory costs borne by the company (Syntetos and Boylan, 2005). A large number of spare part inventories causes high storage costs, while a small number of spare part inventories causes a shortage that has implications for interference of energy production (Porras and Dekker, 2008).

Company $Z$ is one of the energy-producing companies in Indonesia. It is capable of producing energy stably if all the machines operate properly. Machine maintenance is crucial to be carried out by the company so that inventory control of engine spare parts is critical for the company. There are thousands of spare parts in the company that are classified into fast moving, slow moving, and non-moving categories. A spare part is classified as fast moving if it has a demand frequency of more than three times a year. Spare parts with a demand frequency of three or less in a year are classified as slow-moving inventories, while spare parts that have not moved for two years are classified as non-moving inventories.

Fast moving spare part inventories need to be controlled by the company. The high frequency of demand for spare parts in a year encourages companies to calculate safety stock so that the possibility of shortage can be avoided (Putri, 2011). Even though Company $Z$ sets a high service level of $98.14 \%$, it has not calculated the safety stock. The higher the service level set by the company has implications for the greater safety stock that the company should have. This is due to the safety stock that will protect the company from delays in receiving spare parts and the risk of running out spare parts (Budiningsih and Jauhari, 2017).

The risk of shortage on fast moving spare parts in Company $Z$ also arises because most of these spare parts have an intermittent demand pattern. Demand for spare parts varied and there were several periods in which the demand was zero. Intermittent demand occurs due to uncertainty demand from users both in terms of time and quantity demands. In addition, the period of arrival of orders and the characteristics of demand for spare parts are difficult to determine in advance so that the demand is probabilistic. 
The deficiency of safety stock and intermittent demand for spare parts create a risk of distraction to the energy production process caused by the unavailability of spare parts used to repair damaged machines. As a consequence, the company bears a shortage cost which results in a decrease in company profits (Eroglu and Ozdemir, 2007). Therefore, the company needs to implement inventory control with the appropriate model for use in shortage situations due to the absence of safety stock as well as the intermittent demand.

Probabilistic Economic Order Quantity (Probabilistic EOQ) is an appropriate inventory control model used in conditions of highly fluctuating demand and shortage (Eroglu and Ozdemir, 2007). Probabilistic EOQ requires companies to calculate safety stock to reduce the risk of shortage and anticipate fluctuating demand (Aprilia, Dahda and Ismiyah, 2020). This model allows the companies to determine the reorder point, the optimal ordered quantity, and the probability of shortage by calculating the number of safety stock (Trisnawati, 2016). Previous research has shown that companies implementing probabilistic EOQ as their inventory control model are able to place the optimal quantity ordered and achieve inventory cost reduction (Tannady, H ; Pratama, Y., 2019; Kartika and Bakti, 2020; Jung and Klein, 2005; Aprilia, Dahda and Ismiyah, 2020; Eroglu and Ozdemir, 2007).

Based on this background, this study aimed to reduce fast moving spare parts inventory costs by implementing probabilistic EOQ. This study was expected to contribute to Company $Z$ in determining the optimal number of orders as well as determining the amount of safety stock that the company should have. Thus, the risk of fast-moving spare part shortage could be prevented, and shortage costs could be eliminated. Another contribution to this research is in terms of the forecasting method used. Demand forecasting in several previous studies used the moving average-based forecasting method (Ciswondo and Maukar, 2019; Yulius, 2017), while this study used the Croston forecasting method. This method was selected because the pattern of demand for fast-moving spare parts at Company $Z$ is intermittent and lumpy. In addition, shortage costs in this study are also considered in determining the total cost of inventories using probabilistic EOQ. Several previous studies used probabilistic EOQ for the efficiency of inventory costs that only consisted of ordering costs and carrying costs (Rufaidah and Fatakh, 2018; Dyatmika and Krisnadewara, 2017; Rahman and Rudihartati, 2020)

\section{LITERATURE REVIEW}

\subsection{Inventory Control and Shortage}

Inventory is currents assets owned by a company in the form of inventory of raw materials, work in processes, and finished goods (Prawirosentono, 2005). Inventory is also defined as materials or goods that are stored and used to fulfill certain purposes, for example for the production or assembly, spare parts of a machine or equipment (Herjanto, 2009). The existence of inventory is often considered as an idle resource and a waste that creates costs for the company so 
that it must be carefully controlled (Nasution and Prasetyawan, 2008). The ideal condition that the company wants to achieve is that the company is able to fulfill the needs when they are needed without using inventory. However, company with zero inventory has a chance of shortage that results in unfulfilled user needs. Therefore, the existence of inventory needs to be managed carefully so that the needs of the users are still met with the minimum inventory cost (Bahagia, 2006). Inventory control allows companies to manage inventory in the proper amount, proper time, proper condition, as well as proper cost (Beheshti, 2010).

Inventory creates costs for the company. These costs include purchasing costs, ordering costs, carrying costs, and shortage costs (Putri, 2011). Purchasing costs are company expenditures to buy goods from suppliers. Ordering costs are company expenditures for ordering goods from suppliers, such as ordering administration costs, discharge/unloading costs, and quality checking costs. Carrying costs are company expenditures arising from good storage, such as capital costs, damage and depreciation costs, warehouse costs, and handling costs. Shortage costs are company expenditures due to the unavailability of goods when they are needed (Putri, 2011). Ordering costs and shortage costs are inversely proportional to the quantity of goods purchased, while carrying costs and purchasing costs are directly proportional to the quantity of inventory (Putri, 2011).

\subsection{Probabilistic Economic Order Quantity (EOQ)}

Probabilistic inventory control is an inventory control model where the demand and arrival of previous orders is uncertain, but the expected values, variances, and distribution patterns can be predicted and approached based on probability distributions (Lukitosari, 2012). The probabilistic inventory control model emphasizes the importance of safety stock since the demand and lead time that cannot be easily to be determined in advance. This has had several negative effects on the achievement of company's service level where there is a possibility that the inventory will run out when the company has not placed an order, the inventory will run out when the order arrives, or the inventory will not run out when the order arrives (Lukitosari, 2012).

Probabilistic EOQ is one of the methods used in probabilistic inventory control. Probabilistic EOQ is defined as the optimal ordered quantity that minimizes the total inventory cost (Chopra and Meindl, 2004). This model can be used in various situations, such as (i) the demand is certainly known, but the lead time is not certainly known, (ii) the demand is not certainly known, but the lead time is certainly known, or (iii) the demand as well as the lead time is not certainly known (Aprilia, Dahda and Ismiyah, 2020). According to Aprilia, Dahda, and Ismiyah (2020), the Probabilistic EOQ is calculated based on this following formula:

with the additional information:

$$
\mathrm{EOQ}=\sqrt{\frac{2 \mathrm{DS}}{\mathrm{H}}}
$$




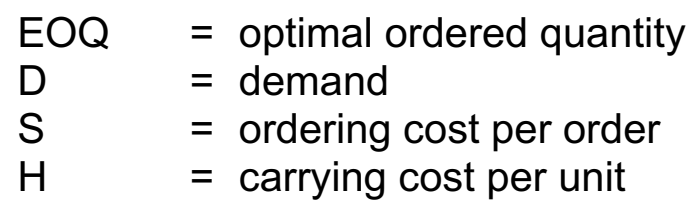

The calculation of safety stock on Probabilistic EOQ plays an important role in preventing shortage. Safety stock in an inventory that is prepared to anticipate any discrepancies between forecasting and actual demand, expected and actual lead time, and other unexpected events to minimize the possibility of shortage (Putri, 2011). The calculation of safety stock based on Putri (2011) uses following formula:

with additional information:

$$
\mathrm{S}_{\mathrm{d}}^{\prime}=\mathrm{S}_{\mathrm{d}} \sqrt{\mathrm{LT}} ; \mathrm{SS}=z \times S_{d}^{\prime}
$$

$\mathrm{S}_{\mathrm{d}}{ }_{\mathrm{d}} \quad=$ standard deviation of demand during the lead lime

$\mathrm{S}_{\mathrm{d}} \quad=$ standard deviation of demand

LT $\quad=$ lead time

SS $\quad=$ safety stock

$\mathrm{z} \quad=$ value form normal distribution table that correlates with a certain service level probability = NORM.S.INV (service level)

Besides determining the optimal ordered quantity and safety stock, probabilistic $E O Q$ is also used to determine the time the company should place an order. Reorder Point is the time the company should place an order with the assumption that demand occurs continuously to reduce the level of existing inventory (Putri, 2011). The calculation of reorder point based on Putri (2011) uses the following formula:

with additional information:

$$
\mathrm{ROP}=(\mathrm{D} \times \mathrm{LT})+\mathrm{z}\left(\mathrm{S}_{\mathrm{d}}^{\prime}\right)
$$

ROP = reorder point

$\mathrm{D} \quad=$ demand

LT $\quad=$ lead time (monthly)

$\mathrm{Z} \quad=$ value from normal distribution table that correlates with a certain service level probability

$S^{\prime}{ }_{d} \quad=$ standard deviation of demand during the lead time

Probabilistic EOQ is an inventory control model that aims to reduce inventory costs (Beheshti, 2010). Probabilistic EOQ is used in situations where the demand and/or the lead time cannot be certainly determined. This model allows the company to prevent shortage through the calculation of safety stock. Therefore, it is necessary to consider the shortage cost in determining the amount of total inventory costs (Eroglu and Ozdemir, 2007). The calculation of total inventory cost according to Putri (2011) uses following formula:

with additional information:

$$
\mathrm{TIC}=\frac{\mathrm{DS}}{\mathrm{Q}}+\frac{\mathrm{HCQ}}{2}+\mathrm{ICzS}_{\mathrm{d}}^{\prime}+\frac{\mathrm{D}}{\mathrm{Q}} \mathrm{kS}_{\mathrm{d}}^{\prime} \mathrm{E}_{(\mathrm{z})}
$$




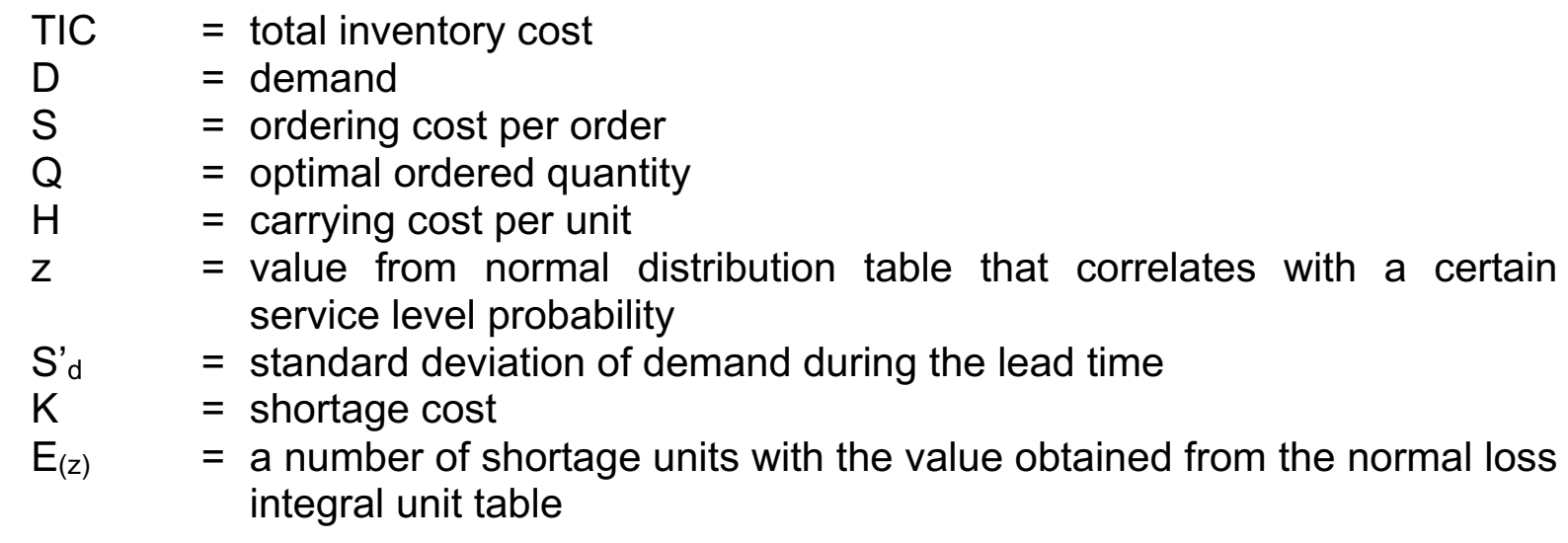

\section{METHOD}

The data in this study include the primary and secondary data. The primary data were collected through interviews with the inventory controller and the warehouse supervisor in Company Z. The interview aimed to get an overview of the actual problems faced by the Inventory and Warehouse Divisions. The secondary data were collected through documentation technique. These data include fastmoving spare part monthly demand for the last five years, fast-moving spare parts ordered quantity, lead time for fast moving spare parts, purchasing costs, ordering costs, carrying costs, and shortage costs.

After the data had been collected, the data was processed using Excel and analyzed using several techniques. First, the Croston method was used to estimate the demand for fast-moving spare parts for the following year. The Croston method is the appropriate method for use in companies whose demand patterns are intermittent and lumpy since it has high accuracy and low error (Willemain, Smart and Joseph H. Shockor, 1994). Forecasting on the Croston method was updated when there is actual demand. On the other hand, the forecast was not updated if the demand is zero (Levén and Segerstedt, 2004) The equation for the Croston method in Budiningsih and Jauhari (2017) is divided into two parts, as follows

$$
\begin{gathered}
\text { If } X(t)=0 \text {, then } S_{t}=S_{t-1} ; I_{t}=I_{t-1} ; q=q+1 \\
\text { If } X(t) \neq 0 \text {, then } S_{t}=\alpha X_{t}+(1-\alpha) S_{t-1} ; I_{t}=\alpha q+(1-\alpha) i_{t-1} ; q=1 \\
M(t)=\frac{S_{t}}{I_{t}}
\end{gathered}
$$

with additional information:

$\mathrm{S}(\mathrm{t}) \quad=$ the estimated size of the quantity demanded

$\mathrm{I}(\mathrm{t}) \quad=\quad$ the average interval between demands

$\mathrm{q}=$ the time interval since the last order

$\mathrm{X}(\mathrm{t}) \quad=$ demand in period $t$

$\mathrm{M}(\mathrm{t}) \quad=$ demand forecasting in period $t$ 
In these equations, $\alpha$ is a constant to smooth forecast. Trial and error were used to determine the value of $\alpha$. The selected $\alpha$ was the $\alpha$ with the lowest levels of Mean Absolute Deviation (MAD), Mean Square Error (MSE), and Mean Absolute Percentage Error (MAPE) (Nasution and Prasetyawan, 2008).

The demand forecasting calculated by the Croston method was used as an input in calculating optimal ordered quantity with Probabilistic EOQ. The next analysis was the calculation of safety stock, reorder point, and total inventory cost. The inventory cost reduction was determined by comparing total inventory cost with Probabilistic EOQ and total inventory cost with company's existing method.

\section{RESULT AND DISCUSSION}

\subsection{Demand Forecasting with Croston Method}

Demand forecasting was carried out on 10 spare parts that were included in the fast-moving category. The results of demand forecasting for the next one year are presented in Table 1.

Table 1. The Results of Demand Forecasting

\begin{tabular}{llllll}
\hline Spare Part & $\begin{array}{l}\text { Average } \\
\text { (Unit) }\end{array}$ & Demand & \begin{tabular}{l} 
Demand \\
Forecasting \\
\cline { 5 - 7 }
\end{tabular} & & \multicolumn{3}{c}{ Forecast Error } \\
\cline { 5 - 7 } & & 6 & MAPE & MAD & MSE \\
\hline Filter fluid & 0.51 & 3 & 23.45 & 0.82 & 1.27 \\
\hline Valve solenoid 3 way & 0.42 & 10 & 17.26 & 0.92 & 1.59 \\
\hline Filter gas & 0.38 & 2 & 18.49 & 2.05 & 7.31 \\
\hline Valve solenoid 2 way & 0.56 & 2 & 19.62 & 0.92 & 1.98 \\
\hline Servovalve hydraulic & 0.23 & 5 & 19.99 & 0.36 & 0.21 \\
\hline Cylinder actuating linear & 0.28 & 5 & 15.84 & 1.86 & 0.47 \\
\hline Filter element hydraulic & 0.35 & 7 & 18.52 & 0.73 & 1.22 \\
\hline Seal assembly boiler & 0.42 & 5 & 12.81 & 0.87 & 1.84 \\
\hline Filter element fluid & 0.48 & 2 & 25.02 & 0.41 & 0.25 \\
\hline O-ring & 0.30 & & & & \\
\hline
\end{tabular}

Table 1 provides information that gas filter has the largest MAD as compared to other spare parts. This indicated that the demand for gas filter in each period had the highest fluctuation. The forecast error on the gas filter was high which indicated the uncertainty of gas filter demand. Therefore, inventory control for gas filter required specific treatment so that shortage could be minimized. Probabilistic EOQ is a method that can be used as a solution to overcome this problem due to the calculation of safety stock (Putri, 2011).

\subsection{Determining Optimal Order Quantity with Probabilistic EOQ}

The policy in Company $Z$ regarding the composition of ordering and carrying costs wherein ordering cost was $25 \%$ of purchasing cost and carrying cost was $10 \%$ 
of purchasing cost. Table 2 below provides information on the optimal quantity that should be ordered by considering the demand, ordering cost, and carrying cost. To get a minimum inventory cost and prevent shortage at the same time, company $Z$ should order 7 units of gas filter in each order.

Table 2. The Results of Probabilistic EOQ

\begin{tabular}{llllll}
\hline Spare Part & $\begin{array}{l}\text { Purchasing } \\
\text { Cost (IDR) }\end{array}$ & $\begin{array}{l}\text { Ordering } \\
\text { Cost (IDR) }\end{array}$ & $\begin{array}{l}\text { Carrying } \\
\text { Cost (IDR) }\end{array}$ & $\begin{array}{l}\text { Demand } \\
\text { Forecasting } \\
\text { (Unit) }\end{array}$ & $\begin{array}{l}\text { Optimal } \\
\text { Quantity } \\
\text { EOQ } \\
\text { (Unit) }\end{array}$ \\
\hline Filter fluid & 30.000 .000 & 7.500 .000 & 3.000 .000 & 6 & 5 \\
\hline Valve solenoid 3 way & 22.062 .500 & 5.515 .625 & 2.206 .250 & 3 & 4 \\
\hline Filter gas & 15.499 .950 & 3.874 .988 & 1.549 .995 & 10 & 7 \\
\hline Valve solenoid 2 way & 104.386 .290 & 26.096 .573 & 10.438 .629 & 2 & 3 \\
\hline Servovalve hydraulic & 13.200 .000 & 3.300 .000 & 1.320 .000 & 2 & 3 \\
\hline Cylinder actuating linear & 41.000 .000 & 10.250 .000 & 4.100 .000 & 5 & 5 \\
\hline Filter element hydraulic & 12.680 .250 & 3.170 .063 & 1.268 .025 & 5 & 5 \\
\hline Seal assembly boiler & 10.155 .600 & 2.538 .900 & 1.015 .560 & 7 & 6 \\
\hline Filter element fluid & 2.255 .500 & 563.750 & 225.500 & 5 & 5 \\
\hline O-ring & 350.000 & 87.500 & 35.000 & 2 & 3 \\
\hline
\end{tabular}

\subsection{Determining Safety Stock}

Company $Z$ has never calculated the safety stock. As a result, the replacement of spare parts on production machines would be troubled if the spare parts run out, engine performance decreased, and extended downtime on production machines. The calculation of safety stock on the Probabilistic EOQ in this study aimed to anticipate the unstable demand movements and the error came from demand forecasting as well as to reduce the risk of shortage. Company $Z$ set the service level at $98.14 \%$ resulting in a Z-value at 2.0836 . Table 3 provides information of safety stock calculated with Probabilistic EOQ. As an illustration, gas filter shortage at Company $Z$ could be prevented if Company $Z$ had a safety stock of 5 units in the warehouse.

Table 3. The Results of Safety Stock

\begin{tabular}{|c|c|c|c|}
\hline Spare Part & $\begin{array}{l}\text { Deviation Standard } \\
\text { of Demand }\end{array}$ & Z Value & $\begin{array}{l}\text { Safety Stock } \\
\text { (Unit) }\end{array}$ \\
\hline Filter fluid & 1.49 & 2.0836 & 4 \\
\hline Valve solenoid 3 way & 0.92 & 2.0836 & 2 \\
\hline Filter gas & 2.21 & 2.0836 & 5 \\
\hline Valve solenoid 2 way & 1.18 & 2.0836 & 3 \\
\hline Servovalve hydraulic & 0.62 & 2.0836 & 1 \\
\hline Cylinder actuating linear & 0.65 & 2.0836 & 1 \\
\hline Filter element hydraulic & 2.94 & 2.0836 & 6 \\
\hline Seal assembly boiler & 0.89 & 2.0836 & 2 \\
\hline Filter element fluid & 1.63 & 2.0836 & 4 \\
\hline O-ring & 0.81 & 2.0836 & 2 \\
\hline
\end{tabular}




\subsection{Determining Reorder Point}

Reorder point is a time when the company has to reorder so that the arrival of the ordered spare parts can be on time. To be on time, the calculation of reorder point is carried out by considering lead time and safety stock (Aprilia, Dahda and Ismiyah, 2020). Table 4 provides information regarding reorder points for each spare part. Company $Z$ ought to order 7 units of gas filter when there were only 6 units of gas filters in the warehouse. Thus, the risk of gas filter shortage was prevented.

Table 4. The Results of Reorder Point

\begin{tabular}{lllll}
\hline Spare Part & $\begin{array}{l}\text { Average } \\
\text { Demand } \\
\text { Forecast (Unit) }\end{array}$ & $\begin{array}{l}\text { Lead Time } \\
\text { (Month) }\end{array}$ & $\begin{array}{l}\text { Safety } \\
\text { Stock (Unit) }\end{array}$ & $\begin{array}{l}\text { Re-order } \\
\text { Point (Unit) }\end{array}$ \\
\hline Filter fluid & 0.50 & 3.33 & 4 & 5 \\
\hline Valve solenoid 3 way & 0.25 & 1.10 & 2 & 2 \\
\hline Filter gas & 0.83 & 1.17 & 5 & 6 \\
\hline Valve solenoid 2 way & 0.17 & 1.67 & 3 & 3 \\
\hline Servovalve hydraulic & 0.17 & 3.00 & 1 & 2 \\
\hline Cylinder actuating linear & 0.42 & 2.00 & 1 & 2 \\
\hline Filter element hydraulic & 0.42 & 2.50 & 6 & 7 \\
\hline Seal assembly boiler & 0.58 & 1.50 & 2 & 3 \\
\hline Filter element fluid & 0.42 & 3.53 & 4 & 5 \\
\hline O-ring & 0.17 & 3.90 & 2 & 2 \\
\hline
\end{tabular}

\subsection{Determining Inventory Cost Reduction}

The total inventory cost in this study was calculated based on the optimal ordered quantity obtained from Probabilistic EOQ. Company Z set a service level at $98.14 \%$. This indicated that there were $1.66 \%$ of demand that could not be fulfilled due to shortage. Therefore, the inventory cost calculation in this study considered the shortage cost. Company $Z$ had a policy that the shortage cost was 10 times the purchase cost which was measured from lost profits due to not being able to meet demand, loses due to break of the production process, and loses due to emergency procurement cost.

Table 5 provides information about the inventory cost reduction obtained if Company $Z$ applied Probabilistic EOQ. The data needed to calculate total inventory cost based on Probability EOQ consisted of demand forecasting, standard deviation of demand, optimal ordered quantity, ordering cost, and carrying cost. These data were presented in Table 2 and 3 . The value of $Z$ was 2.0836 and $E(z)$ was 0.007 were obtained from the value of service level at 0.9814 . Furthermore, the total inventory cost calculated based on Probabilistic EOQ was compared to the total inventory cost calculated based on company's existing method to determine the cost reduction generated by Probabilistic EOQ. 
Table 5. Inventory Cost Reduction

\begin{tabular}{|c|c|c|c|}
\hline Spare Part & $\begin{array}{l}\text { Total Inventory Cost - } \\
\text { Existing Method (IDR) }\end{array}$ & $\begin{array}{l}\text { Total Inventory } \\
\text { Probabilistic } \\
\text { (IDR) }\end{array}$ & Cost Reduction \\
\hline Filter fluid & 59.983 .299 & 29.233 .632 & 30.749 .667 \\
\hline Valve solenoid 3 way & 46.189 .768 & 13.874 .446 & 32.315 .322 \\
\hline Filter gas & 68.518 .322 & 21.508 .662 & 47.009 .660 \\
\hline Valve solenoid 2 way & 119.529 .197 & 64.330 .968 & 55.198 .229 \\
\hline Servovalve hydraulic & 7.108 .591 & 6.253 .514 & 855.077 \\
\hline $\begin{array}{l}\text { Cylinder actuating } \\
\text { linear }\end{array}$ & 76.307 .187 & 27.924 .336 & 48.382 .851 \\
\hline $\begin{array}{ll}\begin{array}{l}\text { Filter } \\
\text { hydraulic }\end{array} & \text { element } \\
\end{array}$ & 58.908 .391 & 16.720 .468 & 42.187 .923 \\
\hline Seal assembly boiler & 10.086 .140 & 8.651 .989 & 1.434 .151 \\
\hline Filter element fluid & 5.656 .330 & 2.154 .000 & 3.502 .330 \\
\hline O-ring & 415.791 & 181.748 & 234.043 \\
\hline \multirow[t]{2}{*}{ Total } & 452.703 .015 & 190.833 .763 & 261.869 .252 \\
\hline & & Cost Reduction & $57.85 \%$ \\
\hline
\end{tabular}

\subsection{Discussion}

Table 5 presents that Probabilistic EOQ provided substantial results for Company $Z$ to succeed cost reduction. The Probabilistic EOQ allowed Company $Z$ to have an inventory cost efficiency of Rp $261.869 .252,00$ or $57.85 \%$. Company $Z$ has often purchased spare parts in small quantities. The probabilistic EOQ enables the company to determine the optimal ordered quantity where this order quantity is usually larger than the order quantity with the existing method. The larger ordered quantity leads in the reduction of ordered frequency. As a result, the ordering cost will decrease. In addition, calculation of safety stock in Probabilistic EOQ allows the company to avoid shortage and this will create shortage cost reduction. This study supports several previous research that the probabilistic EOQ is able to reduce inventory cost (Dania, Mustaniroh and Primasari, 2019; Bintari and Atik Wintarti, 2019; Rufaidah and Fatakh, 2018)

\section{CONCLUSION}

Probabilistic EOQ is one of the inventory controls models that is appropriate for the companies whose demand and or lead time are not certainly determined. The study provides the evidence that Probabilistic EOQ allows the company to reduce its inventory cost by $57.85 \%$. This cost reduction is achieved due to the strong point of Probabilistic EOQ enabling the company to determine optimal ordered quantity while minimizing ordering and carrying costs at the same time. This model also considers the important function of safety stock to reduce the risks of shortage. It is advisable for Company $Z$ to apply Probabilistic EOQ as the inventory control model and to calculate safety stock. This will help Company $Z$ to minimize the risk of spare 
parts shortage that has negative impacts on the break of energy producing process and the downtime of the machine.

This study has weaknesses in calculating ordering, carrying, and shortage costs. The calculation of these costs was conducted based on the policy set by the company. It will be better if activity-based costing is used to calculate these costs. The ordering and carrying costs are traced to each activity in ordering and storage operation according to the cost driver for each activity. Therefore, the ordering and carrying cost will be more accurate and provide better information for the company to control its fast-moving spare parts.

\section{REFERENCE}

Aprilia, P., Dahda, S.S. and Ismiyah, E., 2020. Aplikasi metode always better control dan economic order quantity probabilistik pada perencanaaan dan pengendalian barang jadi. Jurnal Sistem dan Teknik Industri, 1(1), pp.101-110.

Bahagia, S.N., 2006. Sistem Inventori. Bandung: Penerbit ITB.

Beheshti, H.M., 2010. A decision support system for improving performance of inventory management in a supply chain network. International Journal of Productivity and Performance Management, 59(5), pp.452-467.

Bintari, I.A.D. and Atik Wintarti, 2019. Penerapan Metode Economic Order Quantity (EOQ) Dengan Backorder Untuk Optimalisasi Persediaan Bahan Baku Pakan Ternak. Jurnal Matematika, 7(2), pp.104-110.

Budiningsih, E. and Jauhari, W.A., 2017. Analisis Pengendalian Persediaan Spare Part Mesin Produksi di PT. Prima Sejati Sejahtera dengan Metode Continuous Review. PERFORMA : Media IImiah Teknik Industri, 16(2), pp.152-160.

Chopra, S. and Meindl, P., 2004. Supply Chain Management: Strategy, Planning, and Operation. New Jersey: Prentice Hall.

Ciswondo, C. and Maukar, A., 2019. Pengendalian Persediaan Bahan Baku Impor dengan Menggunakan Metode EOQ Probabilistik pada Perusahaan Cat Industri. Journal of Industrial Engineering, 4(2), pp.100-112.

Dania, W.A.P., Mustaniroh, S.A. and Primasari, A., 2019. Probabilistic Economic Order Quantity (EOQ) for The Flour Inventory Control (Case Study in Company Z). In: Proceeding of the 2019 The 3rd International Conference on Digital Technology in Education. [online] Association for Computing Machinery New York NY United States.pp.172-175. Available at:

<https://dl.acm.org/doi/abs/10.1145/3369199.3369248>.

Dyatmika, S.B. and Krisnadewara, P.D., 2017. Pengendalian Persediaan Obat Generik Dengan Metode Analisis Abc, Metode Economic Order Quantity (Eoq), Dan Reorder Point (Rop) Di Apotek Xyz Tahun 2017. Journal of Chemical Information and Modeling, 30(1), pp.1689-1699. 
Eroglu, A. and Ozdemir, G., 2007. An economic order quantity model with defective items and shortages. International Journal of Production Economics, 106(2), pp.544-549.

Herjanto, E., 2009. Sains Manajemen - Analisis Kuantitatif untuk Pengambilan Keputusan. Jakarta: Grasindo.

Jung, H. and Klein, C.M., 2005. Optimal inventory policies for an economic order quantity model with decreasing cost functions. European Journal of Operational Research, [online] 165(1), pp.108-126. Available at:

<https://www.sciencedirect.com/science/article/abs/pii/S0377221704000451>.

Kartika, H. and Bakti, C.S., 2020. Usulan Perbaikan Persediaan Bearing 6004-2RsI Dengan Metode Economic Order Quantity Pada Divisi Sparepart Di Pt Si. (June), pp.17-22.

Levén, E. and Segerstedt, A., 2004. Inventory control with a modified Croston procedure and Erlang distribution. International Journal of Production Economics, [online] 90(3), pp.361-367. Available at:

<https://www.sciencedirect.com/science/article/abs/pii/S0925527303000537>.

Lukitosari, V., 2012. Penentuan Kuantitas Optimal Dan Reorder Point Pada Persediaan Suku Cadang Dengan Distribusi Gamma. Limits: Journal of Mathematics and Its Applications, 9(1), p.33.

Nasution, A.H. and Prasetyawan, Y., 2008. Perencanaan dan Pengendalian Produksi. Yogyakarta: Graha Ilmu.

Porras, E. and Dekker, R., 2008. An inventory control system for spare parts at a refinery: An empirical comparison of different re-order point methods. European Journal of Operational Research, [online] 184(1), pp.101-132. Available at: <https://www.sciencedirect.com/science/article/abs/pii/S0377221706011404>.

Prawirosentono, 2005. Riset Operasi dan Ekonofisika. Jakarta: Bumi Aksara.

Putri, T.R., 2011. Pengendalian persediaan sparepart perusahaan kontraktor tambang PT XYZ dengan menggunakan metode exponential smoothing dan economic order quantity. Depok.

Rahman, T. and Rudihartati, L., 2020. Analisis Logistik Berbasis Biaya Persediaan Rantai Motor Revo Di PT . Astra Internasional. pp.186-193.

Rufaidah, A. and Fatakh, A., 2018. Analisis Pengendalian Persediaan Bahan Baku dengan Menggunakan Economic Order Quantity (EOQ) di PT X. Kaizen: Management System and Industrial Engineering Journal, 1(2), pp.40-45.

Syntetos, A.A. and Boylan, J.E., 2005. The accuracy of intermittent demand estimates. International Journal of Forecasting, 21(2), pp.303-314.

Tannady, H ; Pratama, Y., D., 2019. Spektrum industri. Analisis Perencanaan 
Persediaan Bahan Baku Menggunakan Metode Economic Order Quantity Dengan Pertimbangan Stockout Cost (Studi Kasus Pt. Multi Logam Presisi), 17(2), pp.93-98.

Trisnawati, D., 2016. ANALISA FNS ( Studi Kasus: PG Krebet Baru I, Malang ). Jemis, 4(1), pp.11-18.

Willemain, T.R., Smart, C.N. and Joseph H. Shockor, P.A.D., 1994. Forecasting intermittent demand in manufacturing: a comparative evaluation of Croston's method. International Journal of Forecasting, [online] 10(4), pp.529-538. Available at: <https://www.sciencedirect.com/science/article/abs/pii/0169207094900213>.

Yulius, H., 2017. Pengendalian Perencanaan Produksi Premium Dan Harga Pesan Crude Oil Ekonomis Menggunakan Metode Peramalan Dan Economic Order Quantity ( Studi Kasus Di PT Pertamina RU II Dumai). Edik Informatika, 2(2), pp.220-230. 